\title{
Methane emissions from paddy cultivation and livestock farming in Sarawak, Malaysia
}

\author{
E.K. Peng ${ }^{1, *}, M . A$. Malek $^{1,2}$, and C.S.Tan ${ }^{3}$ \\ ${ }^{1}$ Department of Civil Engineering, Universiti Tenaga Nasional, Jalan IKRAM-UNITEN, 43000 \\ Kajang, Selangor, Malaysia \\ ${ }^{2}$ Centre for Renewable Energy (CRE), Universiti Tenaga Nasional, Jalan IKRAM-UNITEN, 43000 \\ Kajang, Sekangor, Malaysia \\ ${ }^{3}$ Institute of Energy Policy and Research (IEPRe), Universiti Tenaga Nasional, Jalan IKRAM- \\ UNITEN, 43000 Kajang, Selangor, Malaysia
}

\begin{abstract}
In this study, implementation of Tier 1 methodology of 2006 IPCC (Intergovernmental Panel on Climate Change) Guidelines in paddy cultivation and livestock farming has been applied to estimate methane emissions in Sarawak, Malaysia within the years from 1998 to 2009. Methane emission inventory has been developed in this study, based on volume 4, 2006 IPCC Guidelines. Based on cultivation area and livestock population data as input to Tier 1 methodology, variations in paddy cultivation area and amount of livestock has been identified as the main contributor to emissions of methane. Methane emissions increased from 1.61 to $1.72 \mathrm{Gg} \mathrm{CH}_{4} /$ year during 1998 to 1999 . Based on results obtained, the outcomes show that there would be a significant drop of methane emission from buffalo and sheep. Although there are gain and loss in emissions from enteric fermentation, drastic reduction is observed from $0.65 \mathrm{Gg} \mathrm{CH}_{4} /$ year in 1998 to $0.44 \mathrm{Gg} \mathrm{CH}_{4} /$ year in 2009 as well as $0.05 \mathrm{Gg}$ $\mathrm{CH}_{4} /$ year to $0.02 \mathrm{Gg} \mathrm{CH}_{4} /$ year for buffalo and sheep respectively. Simultaneously, methane emissions from manure management of buffalo has decreased from $0.024 \mathrm{Gg} \mathrm{CH}_{4} /$ year in 1998 to $0.016 \mathrm{Gg} \mathrm{CH}_{4} /$ year in 2009 while for sheep, its emission from manure management dropped from $0.002 \mathrm{Gg} \mathrm{CH}_{4} /$ year in 1998 to $0.0007 \mathrm{Gg} \mathrm{CH}_{4} /$ year in 2009. Overall emission from paddy cultivation can be considered in upward trend due to gain from 1998 at $1.61 \mathrm{Gg} \mathrm{CH}_{4} /$ year to $1.67 \mathrm{Gg} \mathrm{CH}_{4} /$ year in 2009 . As an addition, significant rise in methane emission by $0.24 \mathrm{Gg} \mathrm{CH}_{4} /$ year from 2000 to 2006 as well as $0.1 \mathrm{Gg} \mathrm{CH}_{4} /$ year from 2007 to 2009 show momentum gaining in enteric fermentation of cattle. It also indicates future increment in methane emission from cattle which coherently affects the state's emission level. As for emissions from manure management, emissions from cattle, goat and deer are gaining momentum in Sarawak.
\end{abstract}

\footnotetext{
*Corresponding author: pengek@gmail.com
} 


\section{Introduction}

The agriculture sector consists of different variety of activities that may emit greenhouse gases (GHG) directly or indirectly. This includes rice-based production systems with manure management [1]. In Asia, areas of rice cultivation are gaining momentum to meet the food requirement of increasing population. Consequently, methane $\left(\mathrm{CH}_{4}\right)$ emission were higher than in other continents [2].

Both the domestic enteric fermentation and manure management are considered key categories in agriculture sector for both the initial and second national communication of Malaysia. Even though Malaysia was a net sink as reported in second national communication (NC2), increase in methane emission by $13 \%$ from initial $\mathrm{NC}$ to $\mathrm{NC} 2$ indicated emission has been increased throughout the years [3]. The highest source of methane emission in Malaysia is contributed by landfill which made up of $47 \%$ of the total emission. Meanwhile methane emission from rice production and enteric fermentation in domestic livestock contributed $4 \%$ and $2 \%$ of the total emission, respectively. Malaysia has ratified the Kyoto Protocol in September 2002, and as a developing country, it has been categorised into a non-Annex 1 members. This means, Malaysia is not obligated to reduce GHG emissions by any specific percentage. Nevertheless, during the Copenhagen Summit 2009, Malaysia Prime Minister has announced a conditional voluntarily target of $40 \%$ reduction in $\mathrm{CO}_{2}$ intensity of Malaysian GDP by 2020 from a 2005 baseline, subjected to the availability of technology and finance from the Annex I countries.

The conditional voluntarily is applied for all sectors in the country namely energy, industrial processes, agriculture, land use, land use change and forestry (LULUCF) and waste. This paper aims to provide methane emissions from paddy cultivation and livestock farming in Sarawak. The reason methane is chosen is because the gas constituted $23.5 \%$ of the total GHG emissions in Malaysia, which is second largest contributor after carbon dioxide that contributed $75.1 \%$ of the total [3].

\section{Overview of paddy cultivation and livestock farming in Sarawak}

The ensuing section proves that rice cultivations and livestock farming are one of the main source of GHG emission in Malaysia, mainly in the form of methane $\left(\mathrm{CH}_{4}\right)$. As mentioned, emission from rice production and enteric fermentation in domestic livestock contributed $4 \%$ and $2 \%$ respectively in the total methane emission of Malaysia.

The percentage areas for each land use in Sarawak are shown in Fig. 1. The total land use area is recorded as 12 million hectares. It can be concluded that dry forest land contributed to the highest percentage area in Sarawak, followed by land use area of wet and hill paddy, other crops cultivations and swamp forests. Both wet and hill paddy cultivations occupied large portions of land use area and thus, contributed as major source of agricultural on GHG emission in Sarawak. Table 1 exhibits estimation of selected livestock population in Sarawak from 1998 to 2009. 


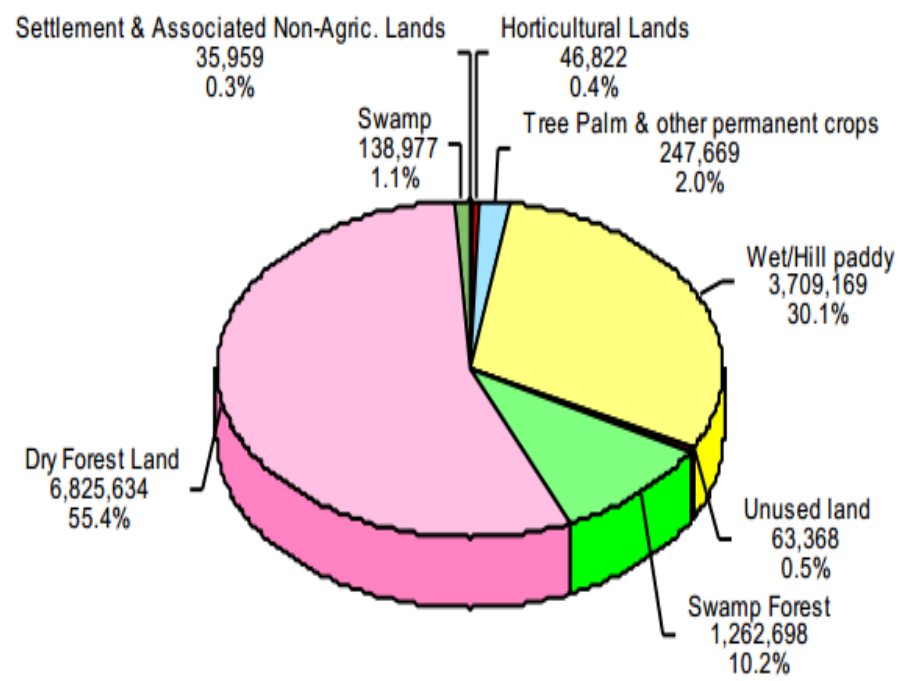

Fig. 1. Area and land use in Sarawak $[4,6]$.

Table 1. Number of livestock in Sarawak $[5,6]$.

\begin{tabular}{|l|l|l|l|l|}
\hline Year & $\mathbf{1 9 9 8}$ & $\mathbf{2 0 0 2}$ & $\mathbf{2 0 0 6}$ & $\mathbf{2 0 0 9}$ \\
\hline Cattle & 8495 & 9532 & 12198 & 13983 \\
\hline Buffalo & 11787 & 10924 & 8765 & 7973 \\
\hline Sheep & 10189 & 5374 & 3408 & 3553 \\
\hline Goat & 10214 & 9078 & 11146 & 14656 \\
\hline Deer & 1384 & 3068 & 4434 & 1489 \\
\hline
\end{tabular}

\section{Material and methods}

Tier 1 methodology of [7] is employed in this study due to difficulties in moving to higher tier methodology resulting from lack of detailed on local data and emission factors [8]. The origin of data used here are from Sarawak's Chief Minister's Department, State Planning Unit, and Publication of Sarawak Facts and Figures. Sarawak is one of the states in Malaysia, situated next to Sabah. It is located at the Eastern Region of Malaysia.

Rice fields in Sarawak are categorized as hill and wet paddy. However, hill paddy are not treated as source of methane emission due to the fact that they are not flooded for adequate time. Hence, only wet paddy is classified as one of the major sources of methane emission. As for livestock, by considering the changes in livestock population during year 1998-2009, a framework capable of estimating $\mathrm{CH}_{4}$ emissions from enteric fermentation and manure management systems based on [7] was established in this study. This study aims to develop a GHG inventory which focuses on $\mathrm{CH}_{4}$ emissions from livestock farming of cattle, buffalo, sheep, goat and deer plus wet paddy cultivation during the period of 1998-2009 in Sarawak.

Similar issues has been addressed and published, but not on GHG emissions specifically from rearing of cattle, buffalo, sheep, goat and deer as well as wet paddy cultivation in environment of Sarawak. Being a developing country, Sarawak is still struggling on Tier 1 methodology in estimating its GHG emissions. 


\subsection{Methodology of emission calculation from wet paddy cultivation}

The 2006 IPCC Guidelines proposed a model to obtain yearly emissions based upon the baseline emission factor $\mathrm{EF}_{\mathrm{c}}$ :

$$
E F_{i}=E F_{c} \cdot S F_{w} \cdot S F_{p} \cdot S F_{o} \cdot S F_{s, r}
$$

where: EFi: adjusted daily emission factor for a particular harvested area, $\mathrm{EF}_{\mathrm{c}}$ : baseline emission factor for continuously flooded fields without organic amendments; $\mathrm{SF}_{\mathrm{w}}$ : scaling factor to account for the differences in water regime during the cultivation period; $\mathrm{SF}_{\mathrm{p}}$ : scaling factor to account for the differences in water regime in the pre-season before the cultivation period; $\mathrm{SF}_{\mathrm{o}}$ : scaling factor should vary for both type and amount of organic amendment applied; SFs,r: scaling factor for soil type, rice cultivar, etc., if available.

A default average baseline emission $\left(\mathrm{EF}_{\mathrm{c}}\right)$ of $1.30 \mathrm{~kg}-\mathrm{CH}_{4} \cdot \mathrm{ha}^{-1} \cdot \mathrm{d}^{-1}$ is suggested in IPCC 2006 Guidelines with an error range of $0.80-2.20$. All scaling factors affecting $\mathrm{EF}_{\mathrm{c}}$ were extracted from 2006 IPCC Guidelines based on local crop and water management practices in Sarawak: rain-fed conditions (it is assumed that there is drought prone; non-flooded preseason of more than 180 days; with farm yard manure as organic amendment). $\mathrm{SF}_{\mathrm{o}}$ is the scaling factor reflecting both the type and amount of organic matter applied. Equation (2) determines SFo (IPCC, 2006):

$$
S F O=\left(1+R O A_{i} \cdot C F O A_{i}\right)^{0.59}
$$

where: SFo: scaling factor for both type and amount of organic amendment applied; $\mathrm{ROA}_{\mathrm{i}}$ :application rate of organic amendment $i$, in dry weight for straw and fresh weight for others (in tonne ha-1); $\mathrm{CFOA}_{\mathrm{i}}$ : conversion factor for organic amendment $\mathrm{i}$ (in terms of its relative effect with respect to straw applied shortly before cultivation) [7]

Due to data constraint, in this study it is assumed that application rate of organic amendment is equal to one (1) as $\mathrm{ROA}_{\mathrm{i}}$. On the other hand, the scaling factors used for wet paddy cultivation are:

SFw : 0.25;SFp : 0.68; $\mathrm{ROA}_{\mathrm{i}}: 1.0 ; \mathrm{CFOA}_{\mathrm{i}}: 0.14 ; \mathrm{ROA}_{\mathrm{i}}: 1 ; \mathrm{SFs}, \mathrm{r}: 1$

Equation 3 is used to estimate $\mathrm{CH}_{4}$ emission from rain-fed conditions:

$$
\mathrm{CH}_{4} \text { Rice }=\sum i\left[\left(E F_{i} \cdot t_{i} \cdot A_{i} \cdot 10^{\wedge} 6\right)\right]
$$

In this study, it is assumed that the cultivation period of paddy in Sarawak is 4 months due to one (1) planting schemes per year practiced. Besides that, it is also assumed that only one (1), namely i condition of ecosystem, water regime, type of organic amendments are practiced for the whole year. These assumptions are made since Sarawak does not experience four (4) seasons throughout the year.

\subsection{Methodology of emission calculation from enteric fermentation}

Formula used for calculating $\mathrm{CH}_{4}$ emissions from enteric fermentation is shown in Equation (4). In developing countries, the recommended value for enteric fermentation emission factor is presented in Table 2 and Table 3 for cattle and other livestock respectively.

$$
\text { Emissions }=E F \cdot\left[\left(N / 10^{\wedge} 6\right)\right]
$$


where: Emissions $=$ methane emissions from Enteric Fermentation, $\mathrm{Gg}_{\mathrm{CH}_{4}} \mathrm{yr}^{-1} ; \mathrm{EF}=$ emission factor for the defined livestock population, $\mathrm{kg} \mathrm{CH}_{4}$ head $^{-1} \mathrm{yr}^{-1} ; \mathrm{N}=$ number of head of livestock species in the country,

Table 2. Tier 1 enteric fermentation emission factor for cattle $\left(\mathrm{kg} \mathrm{CH}_{4} \mathrm{head}^{-1} \mathrm{yr}^{-1}\right)$ [7].

\begin{tabular}{|l|l|l|l|}
\hline Regional characteristics & Cattle category & $\begin{array}{l}\text { Emission } \\
\text { factor }\end{array}$ & Comments \\
\hline $\begin{array}{l}\text { Asia: Small commercialised } \\
\text { dairy sector. Most cattle are } \\
\text { multi-purpose, providing draft } \\
\text { power and some milk within } \\
\text { farming regions. Small grazing } \\
\text { population. Cattle of all types } \\
\text { are smaller than those found in } \\
\text { most other regions. }\end{array}$ & Dairy & 68 & $\begin{array}{l}\text { Average milk production } \\
\text { of } 1,650 \mathrm{~kg} \mathrm{head}^{-1} \mathrm{yr}^{-1}\end{array}$ \\
\hline $\begin{array}{l}{ }^{1} \text { IPCC Expert Group, values represent averages within region, where applicable the use of } \\
\text { more specific regional milk production data is encouraged. }\end{array}$ & $\begin{array}{l}\text { Includes multi-purpose } \\
\text { cows, bulls, and young }\end{array}$ \\
\hline $\begin{array}{l}{ }^{2} \text { The following assumptions have been made in deriving these values: i) mature weights of } \\
\text { animals have been used; ii) cows have been assumed to be non-lactating as lactation levels }\end{array}$ \\
were low and, iii) the mix of bulls and castrates among "males" was undetermined as Cfi \\
value for castrates was not specified.
\end{tabular}

Table 3. Tier 1 enteric fermentation emission factors for buffalo, sheep, goat and deer $\left(\mathrm{kg} \mathrm{CH}_{4}\right.$ head $^{-1}$ $\left.\mathrm{yr}^{-1}\right)$ [7].

\begin{tabular}{|l|l|}
\hline Livestock & $*$ Developing countries \\
\hline Buffalo & 55 \\
\hline Sheep & 5 \\
\hline Goats & 5 \\
\hline Deer & 20 \\
\hline *All estimates have an uncertainty of $\pm 30-50 \%$ \\
Source: Emission factor for buffalo from Gibbs and \\
Johnson (1993); Deer from Clark et al., 2003. \\
\hline
\end{tabular}

Note that the emission factors chosen are based on factors similar to condition in Sarawak. Also, emission factor of other cattle is chosen in this study rather than dairy cattle due to the fact that not all cattle in Sarawak are for the purpose of milk and beef yielding but the cattle are mainly consist of mixture of young, multi-purpose cows and bulls.

\subsection{Methodology of emission calculation from manure management}

Equation (5) shows calculation of $\mathrm{CH}_{4}$ emission from manure management while Table 4 shows manure management methane emission factors by temperature for cattle and buffalo. Meanwhile, Table 5 shows manure management methane emission factors by temperature for sheep, goat and deer.

$$
\mathrm{CH}_{4 \text { Manure }}=\sum\left[(E F \cdot N) /\left(10^{\wedge} 6\right)\right]
$$


where: $\mathrm{CH}_{4 \text { Manure }}=\mathrm{CH}_{4}$ emissions from manure management, for a defined population, $\mathrm{Gg}$ $\mathrm{CH}_{4} \mathrm{yr}^{-1} ; \mathrm{EF}=$ emission factor for the defined livestock population, $\mathrm{kg} \mathrm{CH}_{4} \mathrm{head}^{-1} \mathrm{yr}^{-1} ; \mathrm{N}=$ the number of head of livestock species in the country

Table 4. Manure management methane emission factors by temperature for cattle and buffalo (kg $\mathrm{CH}_{4}$ head $\left.^{-1} \mathrm{yr}^{-1}\right)$ [7].

\begin{tabular}{|c|c|c|}
\hline \multirow[t]{3}{*}{ Regional characteristics } & \multirow[t]{3}{*}{$\begin{array}{l}\text { Livestock } \\
\text { species }\end{array}$} & $\begin{array}{lll}\mathrm{CH}_{4} \text { emission } & \text { factors by } \\
\text { average annual } & \text { temperature } \\
\left({ }^{0} \mathrm{C}\right) & & \\
\end{array}$ \\
\hline & & Warm \\
\hline & & $\geq 28$ \\
\hline \multirow{3}{*}{$\begin{array}{l}\text { Asia: About half of cattle } \\
\text { manure is used for fuel with } \\
\text { the remainder managed in } \\
\text { dry systems. Buffalo } \\
\text { manure is managed in } \\
\text { drylots and deposited in } \\
\text { pastures and ranges. }\end{array}$} & $\begin{array}{l}\text { Dairy } \\
\text { Cows }\end{array}$ & 31 \\
\hline & $\begin{array}{l}\text { Other } \\
\text { Cattle }\end{array}$ & 1 \\
\hline & Buffalo & 2 \\
\hline
\end{tabular}

Table 5. Manure management methane emission factors by temperature for sheep, goat and deer $(\mathrm{kg}$ $\mathrm{CH}_{4}$ head $\left.^{-1} \mathrm{yr}^{-1}\right)$ [4].

\begin{tabular}{|l|l|}
\hline Livestock & $\begin{array}{l}\mathrm{CH}_{4} \text { emission factor by } \\
\text { average annual } \\
\text { temperature }\left({ }^{0} \mathrm{C}\right)\end{array}$ \\
\cline { 2 - 2 } & Warm $(>25)$ \\
\hline Sheep & 0.20 \\
\hline Goats & 0.22 \\
\hline Deer ${ }^{\mathrm{a}}$ & 0.22 \\
\hline $\begin{array}{l}\text { The uncertainty in these emission factors is } \pm 30 \% . \\
\text { a Sneath et al. }(1997)\end{array}$ \\
\hline
\end{tabular}

For cattle and buffalo, manure management methane emission factors are obtained from warm temperature, which is $\geq 28^{\circ} \mathrm{C}$. This is justified by the average temperature in Sarawak which is $32-33^{0} \mathrm{C}$ Emission factor of other cattle is chosen in this study.

\section{Results and discussions}

The annual emission of methane from paddy cultivation together with enteric fermentation and manure management in Sarawak is illustrated in Fig. 2 to 4 respectively. Unit for methane emission is Giga gram $(\mathrm{Gg}) \mathrm{CH}_{4} /$ year. 


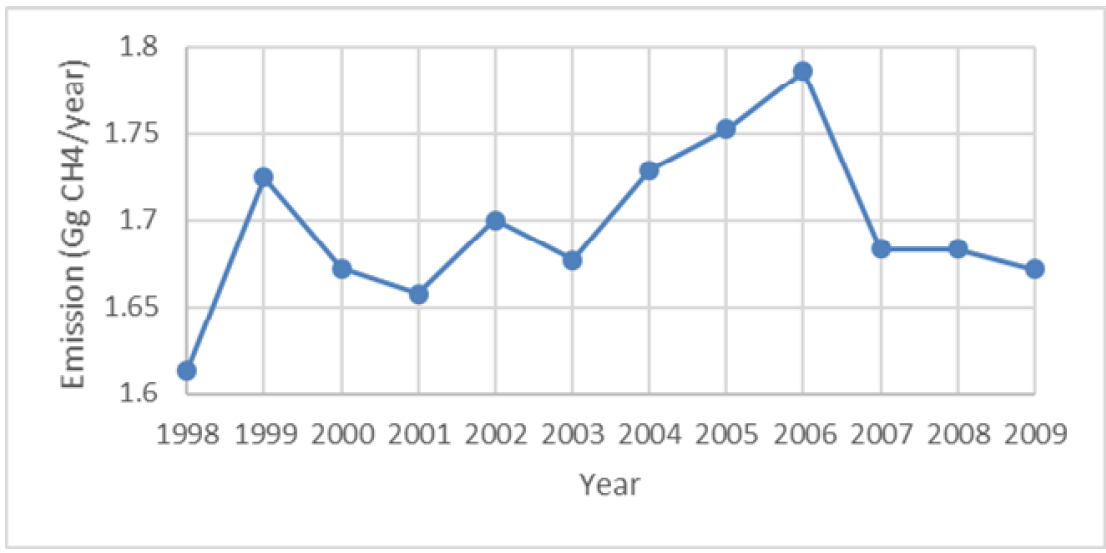

Fig. 2. Annual methane emission from paddy cultivation in Sarawak.

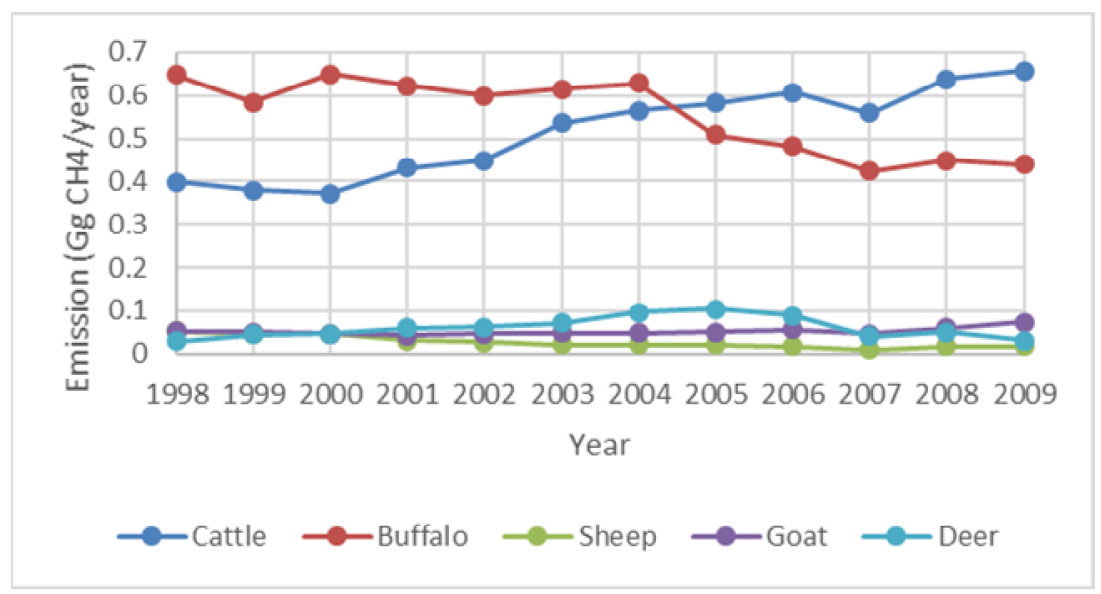

Fig. 3. Annual methane emission from enteric fermentation of livestock in Sarawak.

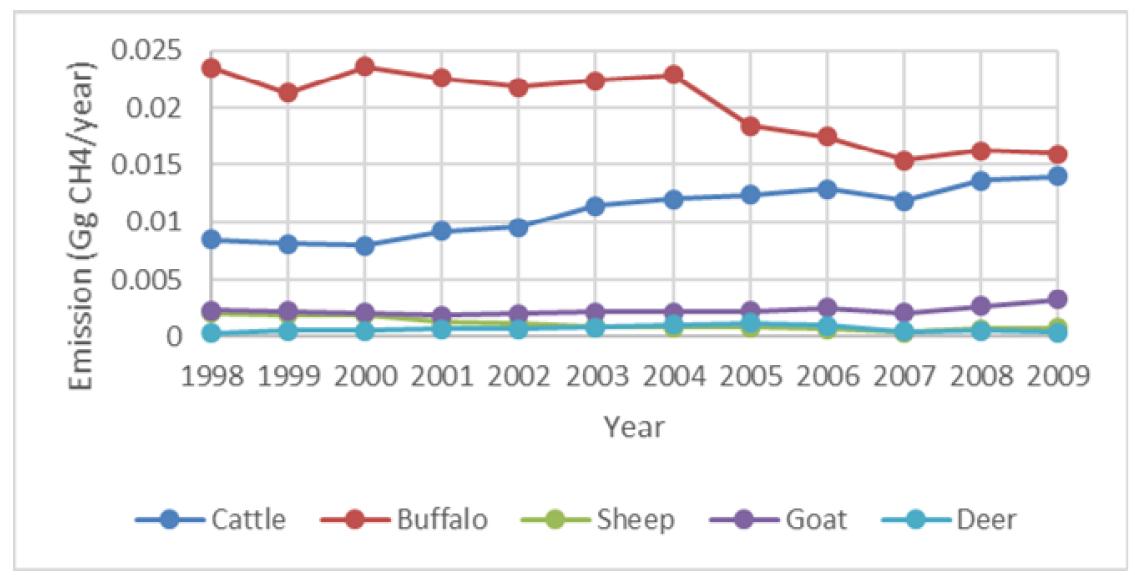

Fig. 4. Annual methane emission from manure management of livestock in Sarawak. 


\subsection{Cultivation of wet paddy}

Fig. 2 shows the annual methane emission from paddy cultivation between 1998 and 2009. Practice in Sarawak is such that all animal waste is applied back to the field. The range of $\mathrm{CH}_{4}$ emissions from wet paddy is 1.61 to $1.79 \mathrm{Gg} \mathrm{CH}_{4}$ /year as shown in this figure. The graph exhibits an incremental trend from 1998 at (1.61 $\mathrm{Gg} \mathrm{CH}_{4} /$ year) till $1999(1.72 \mathrm{Gg}$ $\mathrm{CH}_{4} /$ year). The abrupt increasing trend from 2003 at $1.68 \mathrm{Gg} \mathrm{CH}_{4} /$ year to year 2006 at 1.79 $\mathrm{Gg} \mathrm{CH}_{4} /$ year shows an alarming rate of $\mathrm{CH}_{4}$ emissions. However, the emission from 2006 to 2009 has shown decreasing trend.

The upward emission trend is explained by changes in cultivation areas of paddy. Based on the results obtained in this study, it can be concluded that the gain in area will lead to a rise in $\mathrm{CH}_{4}$ emissions. Simultaneously, [1] reported that a minor increase rate in the area for rice cultivation from $0.8 \%$ to $1 \%$ will emit an additional 0.10 tons/year of methane.

Mitigation options suggested in NC2 mentioned that water management infrastructures need to be tailored towards alternating irrigating and draining once or several times during the growing and fallow seasons. With the proper set up of water control infrastructures and good water management especially in the main granary areas, methane emissions from rice cultivation can be reduced [3].

\subsection{Livestock - cattle}

Fig. 3 presents annual methane emission from enteric fermentation of livestock between 1998 and 2009. Based on the figure, it is observed that methane emission from enteric fermentation of cattle increases in upward trend through the overall study duration. The trend increases steadily from $0.56 \mathrm{Gg} \mathrm{CH}_{4} /$ year in 2007 to $0.66 \mathrm{Gg} \mathrm{CH}_{4} /$ year in 2009 . Chances are the number of population for cattle have increased via breeding due to huge demand. The trend is predicted to increase after year 2009 if and only if the demand continues to rise. As evidenced from Malaysia's NC2, GHG emissions will increase proportionally to the number of livestock kept. Technologies on reducing emissions from enteric fermentation are presently not economically feasible especially when Malaysia is importing most of its concentrate feed [3].

Fig. 4 demonstrates annual time series of methane emission from manure management of livestock between 1998 and 2009. From the figure, range of emission for cattle varies from $0.008 \mathrm{Gg} \mathrm{CH}_{4}$ /year to $0.014 \mathrm{Gg} \mathrm{CH}_{4} /$ year. It is shown that the overall emission increases with increase in population during 1998-2009. It is estimated that the emission after 2009 will continue to increase as the amount of cattle determines the amount of manure produced, thus affecting the emission. According to [10], the amount of methane released is related to the composition of manure. The more the amount of cattle, the higher the amount of methane generated due to increased manure produced.

\subsection{Livestock - buffalo}

From Fig. 3, methane emission from enteric fermentation of buffaloes in Sarawak showed overall decreasing trend. Abrupt decrease is from $0.63 \mathrm{Gg} \mathrm{CH}_{4} /$ year in 2004 to $0.42 \mathrm{Gg}$ $\mathrm{CH}_{4} /$ year in 2007. The decreasing trend will continue to fall after year 2009 when the population of buffaloes are lesser. In this case, uncertainty may occur due to lack of detailed local data obtained. This is further proven by [11] who stated that emissions calculated using Tier 1 default IPCC emission factor were about 9.65 to $10.95 \%$ greater than emissions utilizing Tier 2 methodology of IPCC. Therefore collaboration and cooperation with data providers must be increased in order to improve data disaggregation. 
From Fig. 4, methane emission from manure management for buffaloes varies from 0.015 to $0.024 \mathrm{Gg} \mathrm{CH}_{4} /$ year throughout year 1998-2009. This is due to the lessened population of buffaloes in Sarawak that brings to reduced amount of manure produced, thus lesser the methane released.

\subsection{Livestock - sheep}

Based on methane emission from enteric fermentation of sheep in Fig. 3, there is an abrupt decrease in methane emission starting from year 1998 at $0.051 \mathrm{Gg} \mathrm{CH}_{4} /$ year to year 2007 at $0.009 \mathrm{Gg} \mathrm{CH}_{4} /$ year. This is compatible with the average value obtained from Table 2 which demonstrated a decreasing trend throughout the years. Chances are the emission in the future after year 2009 will continue to decrease or maintain at the same level as in year 2009 due to low growth rate of sheep resulting from lower demand in the market in Sarawak. This is proven by reduction of sheep amount from year 1998 at 10189 to year 2007 at 1912.

For methane emission from manure management as shown in Fig. 4, the range of emission during 1998-2009 for sheep varies from 0.0006 to $0.002 \mathrm{Gg} \mathrm{CH}_{4} /$ year. The emission trend is probably reducing after year 2009. This is due to the way of feeding the sheep which will affect the portion of manure that decompose anaerobically. It is recommend that the manure of sheep shall be composted via aerobic composting in order to suppress emissions of methane.

\subsection{Livestock - goat}

Based on methane emission from enteric fermentation of goats in Sarawak, the trend of methane emission from enteric fermentation exhibited overall increasing trend from 0.05 to $0.06 \mathrm{Gg} \mathrm{CH}_{4} /$ year. The trend of methane emission will probably continue to increase after year 2009, depending on the goats' population. Similar to sheep, the factor that affect methane emission from enteric fermentation include population of goat kept. As shown in Table 1, quantity of goat has increased from year 2006 at 11,146 to year 2009 at 14,656, resulting in gain in emission. One also noticed that the default Tier 1 enteric fermentation emission factors provided by [4] is higher for developed nations compared to Malaysia. The variations in per head emissions originated from the amount and quality of feed intake in Sarawak.

For methane emission from manure management in Fig. 4, the range of emission for goat varies from 0.002 to $0.003 \mathrm{Gg} \mathrm{CH}_{4}$ /year. The use of composted manure in agricultural soils should be encouraged as it is a food source for soil microbes. Interactions between the manure and the microbes will increase the content of organic matter making the soil more fertile and sustainable for crop production while at the same time reducing GHG emissions both from manure decomposition and fertiliser usage [3].

\subsection{Livestock - deer}

Based on methane emission from enteric fermentation of farmed deer in Sarawak, overall increasing trend is spotted from 0.04 to $0.05 \mathrm{Gg} \mathrm{CH}_{4} /$ year during year 1998-2009. The methane emission from enteric fermentation after year 2009 will probably be reduced, as a result of decreasing population of deer. The slight increase in methane emission of enteric fermentation from 1998 till 2005 is due to ruminant livestock characteristics of the deer. Besides, default emission factors from 2006 IPCC Guidelines were used instead of detailed 
local emission factors. Therefore, it is suggested that research and development of local emission factors must be enhanced [8].

For methane emission from manure management, the range of emission for farmed deer varies from 0.0005 to $0.0006 \mathrm{Gg} \mathrm{CH}_{4} /$ year during year 1998-2009. As mentioned, composted manure brings various benefits. With the increase in prices of chemical fertilisers, the demand for composted manure is increasing, making it a good opportunity for farmers to earn some extra income. Adoption of this technology is easy and reduction of $\mathrm{CH}_{4}$ emissions from deer manure can be achieved.

In summary, methane emission from wet paddy cultivation demonstrated upward trend from 1998 to 2009. Simultaneously, emission of methane from both enteric fermentation and manure management of cattle, goat and deer showed a raise in emission, while methane emission from enteric fermentation of buffalo and sheep experienced significant drop in emission. This is due to lower quality feed intake in Sarawak conditions. As for the methane emission from manure management, not much changes has been observed for buffalo except for that of emission from sheep which exhibited abrupt emission reduction. Last but not least, developing countries are expected to invest in rapid growth of animal production and consumption, which is much more different than developed countries. Hence emission from livestock shall be monitored [12].

\section{Conclusion and recommendation}

This study provides a tool that is capable of indicating the trend of methane emissions from paddy cultivation, enteric fermentation and manure management from livestock farming in Sarawak during the period of 1998-2009. Based on the emissions from paddy cultivation, it can be concluded that the emissions of methane from wet paddy varies depending upon the cultivation area. This is because of the varying area of cultivation and different cultivation practices. In addition, the geographic conditions of Sarawak allow for once per year of wet paddy cultivation. Hence, due to the importance of paddy cultivations for food security, it is recommended that the Malaysian Agricultural Research and Development Institute (MARDI) to install various apparatus on the paddy fields in Sarawak, in order to capture actual methane emissions. It is also recommended that MARDI to innovate paddy genetics that could emit less methane while providing more yield in the paddy fields.

In conclusion, even if we in this developing country faces many doubts on activity data collected, methods of data processing, methods of data and information presentation to the public, it is our responsibilities to pursue on these GHG estimation in order to determine the quantity of actual GHG being emitted by human activities such as crop cultivation, livestock farming and land use change so that Malaysia's voluntary indicator of up to a $40 \%$ reduction in the GHG emissions intensity of GDP compared to 2005 values by 2020 will become a reality as announced by the Malaysia Prime Minister at the UNFCCC COP 15 in Copenhagen. $\mathrm{CH}_{4}$ which is produced in continuously flooded rice fields can be substantially reduced with more precise water management; and proper manure management can reduce $\mathrm{CH}_{4}$ emissions, produce bio-fertilisers and facilitate the capture of biogas to serve as an energy source. It is hoped that the mitigation measures will reduce methane emissions thus reducing the total GHG footprint in Sarawak. Timely transfer of environmentally friendly and sound technologies and access to adequate financing under the UNFCCC (United Nations Framework Convention on Climate Change) will ensure Malaysia's achievement of the lower emissions per unit GDP scenario.

The authors would like to thank UNITEN R\&D Sdn. Bhd for Grant U-EN-CR-14-12 that enables collaboration between them which leads to the development of this paper. Any of the opinions, 
findings and conclusions expressed in this paper are those of the authors and do not necessarily reflect the views of UNITEN R\&D Sdn. Bhd.

\section{References}

[1] J. Maclean, B. Hardy, G. Hettel, Rice Almanac, $4^{\text {th }}$ edition: Source Book for One of the Most Important Economic Activities on Earth, International Rice Research Institute, Laguna, Philippines, (2013)

[2] M. Cao, K. Gregson, S. Marshall, J.B. Dent, O.W. Heal, Global methane emissions from rice paddies, Chemosphere, 33(5), 879-897, (1996)

[3] Ministry of Natural Resources and Environment, Malaysia, Malaysia's Second National Communication (NC2) to the UNFCCC, (2011), Retrieved on August 18, 2016 from http:// http://unfccc.int/resource/docs/natc/malnc2.pdf

[4] Land and Survey Department, Sarawak, Area and land use in Sarawak, (2013), $\begin{array}{lllll}\text { Retrieved on } & \text { May } & 15, & \text { from }\end{array}$ http://www.landsurvey.sarawak.gov.my/modules/web/index.php

[5] Department of Agriculture, Sarawak, Sarawak Agriculture Statistics, (2010), Retrieved on June 20, 2016 from http://www.doa.sarawak.gov.my/modules/web/index.php

[6] Sarawak Agriculture Statistics, Sarawak Facts and Figures, State Planning Unit, Chief Minister's Department, Sarawak, Malaysia, (2010)

[7] H.S. Eggleston, L. Buendia, K. Miwa, T. Ngara, K. Tanabe, The Intergovernmental Panel on Climate Change, 2006 IPCC Guidelines for National Greenhouse Gas Inventories, Volume 4: Agriculture, Forestry and Other Land Use, Institute for Global Environmental Strategies, Kanagawa, Japan, (2006)

[8] Ministry of Natural Resources and Environment, Malaysia, Biennial Update Report (BUR) to the UNFCCC, (2015), Retrieved on July 5, 2016 from http://www.nre.gov.my/sites/TNC-BUR/Documents/BUR_Malaysia_Final.pdf/

[9] S. Anand, R.P. Dahiya, V. Talyan, P. Vrat, Investigations of methane emissions from rice cultivation in Indian context, Environment Int., 31(4), 469-482, (2005)

[10] R.O. Yusuf, Z.Z. Noor, A.H. Abba, M.A. Hassan, M.F. Din, Methane emission by sectors: A comprehensive review of emission sources and mitigation methods, Renewable and Sustainable Energy Reviews, 16(7), 5059-5070, (2012)

[11] A.K. Patra, Trends and projected estimates of GHG emissions from Indian livestock in comparisons with GHG emissions from world and developing countries, AsianAustralasian J. of Animal Sciences, 27(4), 592-599, (2014)

[12] V. Sejian, R. Lal, J. Lakritz, Measurement and prediction of enteric methane emission, Int. J. Biometeorol, 55, 1-16, (2011) 